\title{
Indigenisation of Christianity Among the Asantes: Truly Asante and Truly Christian?
}

\author{
Anthony Kofi Anomah ${ }^{1}$ \\ ${ }^{1}$ Spiritan University College, Ejisu - Ghana.
}

\begin{abstract}
Christianity was rekindled in Asante Kingdom in the Gold Coast (Ghana) in the 15th century by European missionaries. The Asante converts were taught to abandon their religion to become Christians. However, some Asante Christians, and in fact, this could be true about other contexts in Africa and elsewhere, remain dual religious, accepting Christianity on one hand and Asante Traditional Religion on the other. In this study, the author seeks to find out why some Asante Christians resort to some elements of Asante Traditional Religion in times of crisis and whether an Asante can be truly Asante and truly Christian. The study used the convergent mixed-methods case study approach in the Roman Catholic Church, the Methodist Church Ghana and the Church of Pentecost in Ejisu Juaben Municipality to collect primary data using a questionnaire and an interview guide. Using the Krejcie and Morgan Sample Size Determination Table, three hundred and seventy-seven (377) Christians with diverse backgrounds and roles out of a total population of 20,000 Christians from the three Churches were surveyed. In addition, nine (9) ordained ministers from the three denominations were interviewed purposively in the study because of their knowledge and expertise in the topic. The study found out that some Asante Christians are dual religious because they are pragmatic and resort to either Christianity or some elements of Asante Traditional Religion in times of crisis for solutions to their problems. The study recommends that Asante Christians should appreciate the role of Asante Traditional Religion in preparing the soil for the establishment of Christianity; dialogue with Asante Traditional Religion and enculturate or integrate the gospel with Asante Traditional Religion to become truly Asante and truly Christian.
\end{abstract}

Keywords: Asante, Christian, Christianity, Traditional Religion, dialogue, inculturation.

\author{
Correspondence: \\ Anthony Kofi Anomah \\ Email: anomah13@gmail.com \\ Manuscript \\ Received 6th November 2020, \\ Accepted 25th November \\ 2020, \\ Published online 8th \\ December 2020.
}

\section{INTRODUCTION}

The first phase of Christianity in Africa in the 1st century of the Christian era took root in North Africa in such places as Egypt, Libya, Sudan and Ethiopia with great figures such as Tertullian, Origen, Clement of Alexandria, Cyprian, Monica and Augustine. This phase of Christianity in Africa was wiped away completely by the Islamic threat of the 7 th century A.D.

Christianity was rekindled in the Gold Coast (Ghana) by the Portuguese Catholic seafarers and missionaries in the 15th century. ${ }^{1}$ They settled in Elmina on January 20, 1482. ${ }^{2}$ The Catholic Church was followed by "the United Brethren or the Moravian Church (1737), the Society for the Propagation of the Gospel in Foreign Paris (1752), the Basel Evangelical Missionary Society (1828), the Wesleyan Methodist Missionary Society (1834) and the North German Missionary Society or the Breman Mission (1847)." "3 The Catholic missionary efforts from 1470-1880 were unsuccessful due to the Trans-Atlantic Slave Trade, the missionaries' attitude towards local people, the missionaries' pre-mature

\footnotetext{
Henry, Koren. Spiritan West Africa Memorial for Gambia, Sierra Leone, Liberia and Ghana - 1842-1996 (Bethel Park, PA: Spiritus Press, 1997), 26

Koren. Spiritan West Africa Memorial for Gambia, Sierra Leone, Liberia and Ghana 26.

Pashington Obeng, Asante Catholicism: Religious and Cultural Reproduction Among the Akan of Ghana, (New York, NY: E. J. Brill, 1996$), 99$.
} 
deaths, the local people's suspicion of the missionaries and the lack of translation of the Bible into the local language. ${ }^{4}$ The flourishing Christianity today began in the 19th century with the Roman Catholic Church, the Presbyterian Church Ghana, the Methodist Church Ghana and many more. Since then, the other Christian denominations have flourished in the Gold Coast (Ghana). Today, there are the Pentecostal, Charismatic and Neo-Pentecostal, Neo-Charismatic and African Independent Churches in Ghana. These form part of the third phase of Christianity in Ghana (Africa).

The Christian missionaries urged the convert to "turn from the worship of traditional gods to the worship of the all-sufficient One God." ${ }^{5}$ Williamson observed that the individual Akan was called out of his society to abandon his traditional past in which he had been nurtured, accept the Christian religion, look down on traditional religion, and to substitute the Akan worldview with the European worldview. ${ }^{6}$

The Asante convert enters the Church as a traditional Asante in a foreign institution whose demands and concepts are foreign to him/her. However sincere his/her attachment to the Church, "he cannot deny himself or the society within which he has been nurtured. He carries within himself his traditional outlooks and attitude, the religious and social valuations of his people. The missionary aimed to draw the convert away from his traditional life towards what the missionary considered to be a proper expression, civilized and Christian, of his new faith."7 To a large extent, many Christians have lost touch with the traditional pattern of society and traditional religion.

Yet while many Christians have abandoned the traditional view of life, there is still fear of witchcraft, curses and evil forces. There are some Asante Christians who conform to Church discipline but are not emancipated from traditional beliefs and practices. ${ }^{8}$ They seek personal security and success in Asante Traditional Religion. Some Asante ${ }^{9}$ Christians live in two worlds, the world of Asante Traditional Religion and Christianity. The modern-day Asante, whether literate or illiterate or an adherent of Asante Traditional Religion or Christian, views the world in the same way as his/her forefathers did. The difference between the two generations is that "where the men of old enjoyed a stable society and relied unworried upon the efficacy of state-gods and spirit-ancestors to preserve it so, the new man uncertain in his changing world, seeks frantically for 'power' wherever it may be found." ${ }^{10}$ While adherents of Asante Traditional Religion believe in the Supreme Being, spirits (good and evil), ancestral veneration, life after death, curses, charms, amulets and witchcraft, Christians do not approve of curses, charms, amulets and witchcraft powers.

Despite over 150 years of Christianity among the Asantes, some Asante Christians resort to Asante Traditional Religion whenever they are confronted with unexplainable circumstances in their lives, which they often attribute to witchcraft or evil spirits. Gbortsu observed that "many African societies are showing signs of increasing spiritual insecurity, affecting also Catholics and the Christian faithful in general. Amid political, socio-economic or personal difficulties, many fulfil their need for spiritual support by resorting to the traditional religions."11

In this article, the author seek to find out why some Asante Christians resort to some elements of Asante Traditional Religion in times of crisis and whether an Asante can be truly Asante and truly Christian?

\section{METHODOLOGY}

The study used the convergent mixed-methods case study approach. The core assumption is that combining qualitative and quantitative data provides a more complete understanding of a research problem than either approach alone. Primary data was collected using a questionnaire and an interview guide. Three (3) mainline Churches were selected from Ejisu-Juaben Municipality based on their visibility and population in the municipality to represent the mainline Roman Catholic Church, the mainline Protestant Churches (the Methodist Church Ghana) and the Pentecostal Movement of Ghana (the Church of Pentecost). The total population of Christians of 16-years and above in the three Churches was about twenty thousand $(20,000)$, eight thousand $(8,000)$ Roman Catholics, seven thousand $(7,000)$ Methodists and five thousand $(5,000)$ Pentecostals as shown in the table below:

Table 1: shows the distribution of numbers according to Churches (denomination)

\begin{tabular}{|l|l|l|l|l|}
\hline Denomination & Total Number of Congregation & Percentage (\%) & Ratio (:) & Sample Size (n) \\
\hline Roman Catholic Church & 8,000 & 40 & 4 & 151 \\
\hline Methodist Church Ghana & 7,000 & 35 & 3 & 132 \\
\hline
\end{tabular}

\footnotetext{
Obeng, Asante Catholicism: Religious and Cultural Reproduction Among the Akan of Ghana, 99.

S.G. Williamson, Akan Religion and the Christian Faith,:A Comparative Study of the Impact of the Two Religions, (Accra: University of Ghana Press,)169.

Williamson, Akan Religion and the Christian Faith, 170.

Williamson, Akan Religion and the Christian Faith, 171.

Williamson, Akan Religion and the Christian Faith, 172.

The Asantes of Ghana form part of the largest ethnic group in Ghana and Ivory Coast Called Akan. In this work, Asante and Akan will be used frequently.

10 Williamson, Akan Religion and the Christian Faith, 167.

1 Fabian Gbortsu, "Facing Spiritual Insecurity: Christian Faith and the Return of Catholics to the African Traditional Religion in Challenges to Church's Mission in Africa (edited by Fabrizio Meroni). (Rome: The Factory S.r.1., 2020), 153, 155.
} 


\begin{tabular}{|l|l|l|l|l|}
\hline The Church of Pentecost & 5,000 & 25 & 2 & 94 \\
\hline Total Population & 20,000 & 100 & & 377 \\
\hline
\end{tabular}

Source: Field Survey from Church leaders, 2017

The sample size was determined using Krejcie and Morgan Sample Size Determination Table, $1970 .{ }^{12}$ Krejcie and Morgan recommend that for a population of 20,000, a minimum sample size of three hundred and seventy-seven (377) was to be selected. Thus, three hundred and seventy-seven (377) Christians with diverse backgrounds and roles in the Roman Catholic Church, Methodist Church Ghana and the Church of Pentecost were selected in proportion to the population of each Church to answer survey questionnaires administered to them and supervised with the help of four research assistants. Also, nine (9) ordained ministers from the Roman Catholic Church, the Methodist Church Ghana and the Church of Pentecost were also selected for in-depth interviews using purposive sampling technique in the ratio of 4:3:2 respectively. Analyses of the questionnaire were made using the Statistical Package of Social Sciences (SPSS) and thematic analysis of the interviews.

\section{RELIGIOUS TRADITIONS}

There are some Christians who believe that no one can go to God, the Father except through the Son, Jesus; and there is no salvation in anyone except Jesus. ${ }^{13}$ They are called exclusivists. On the other extreme are the pluralists. They are Christians who believe that no one religion can claim the monopoly of the truth at the exclusion of other religions in God's revelation and plan to save all humankind. They believe that no one religion can be used as a lens or yardstick to measure other religions because religion embraces more than what an outsider perceives. ${ }^{14}$ Similarly, all human beings are born into cultures; and each one is influenced by the context in which s/he is born. Thus, one's idea of everything, including God is determined by the culture in which $\mathrm{s} /$ he is born. Therefore, there are no objective grounds to claim that one person's religious tradition is better than the other. Instead, each religious tradition is unique. Therefore, no religion can claim authenticity alone while looking down on others as inauthentic. ${ }^{15}$

In the middle of these two extreme positions is the inclusivists who believe that there is supernatural grace present in both non-Christian religions and Christian religions even if the people are not aware. Given this Rahner says, "there are supernatural, grace-filled elements in non-Christian religions." 16 Rahner argues that before the birth of Christ and the proclamation of the gospel, non-Christian religions had elements of a natural knowledge of God even if they were mixed up with human depravity as a result of original sin. ${ }^{17}$ Non-Christian religions contain supernatural elements arising out of God's grace which is freely given to humankind as a gift on account of Christ. Thus, non-Christian religions can be recognised as lawful religions despite the error and depravity they may contain. ${ }^{18}$ This is because God intended from the beginning of creation to save all humankind (1 Tim 2:4). Thus, the Second Vatican Council teaches that the Church "does not wish to impose a rigid uniformity in matters which did not involve the faith or the good of the whole community." 19 Rather, the Church "respects and fosters the qualities and talents of various races and nations" in so far as they do not involve superstition or error; and teaches that even persons without the historical message of Christianity, even atheists, can be influenced by God's redeeming grace, and be saved. ${ }^{20}$

\section{RELIGION AND CULTURE}

It is impossible to treat religion without reference to a culture or vice versa. ${ }^{21}$ Mbiti supports this when he said, "Religion permeates into all departments of life so fully that it is not always easy or possible to isolate it." 22 There are as many definitions of culture as there are cultures. According to Niebuhr, culture comprises language, habits, ideas, beliefs, customs, social organisation, inherited, artifacts, technical processes and values. It is the social heritage a person receives and transmits to others in any place or time. It includes speech, education, tradition, myth, science, art, philosophy,

\footnotetext{
12 Robert V Krejcie and Daryle W. Morgan. Determining Sample Size for Research Activities. Educational and Psychological Measurement. (1970), 30, 607-610.

13 Peter Addai-Mensah, \& John K. Opoku, "Christ and the Religions: A Critique of the Pluralistic and the Exclusivist Paradigms," In: Journal of Applied Thought (A Multidisciplinary Approach), 3 no. 1, (2014), 186.

14 Karl Rahner, "Christianity and the Non-Christian Religions" Theological Investigations, (London: Darton, Longman \&Todd Ltd., 1966), 116; Addai-Mensah, \& Opoku, "Christ and the Religions," 183; Anthony Kofi Anomah, "Assessing the Impact of Christianity on African Christians: A Case study of some selected Churches in Ejisu Juaben Municipality." PhD Thesis unpublished, Kwame Nkrumah University of Science and Technology, (Kumasi, 2019).

5 Addai-Mensah, \& Opoku, "Christ and the Religions," 183.

6 Rahner, "Christianity and the Non-Christian Religions," 121.

Rahner, "Christianity and the Non-Christian Religions," 121.

Rahner, "Christianity and the Non-Christian Religions," 121.

Vatican II, The Constitution on the Sacred Liturgy, (Iperu-Remo: Ambassador Publications, 1998), SC 37, 13.

Rahner, "On the Importance of the Non-Christian Religions for Salvation," 290; LG 16; AG, 7; GS 22.

Williamson, Akan Religion and the Christian Faith, 112.

John S. Mbiti, African Religions and Philosophy. (London: Heinemann, 1998), 1.
} 
government, law, rite, beliefs, inventions and technologies. ${ }^{23}$

Religion and culture are essentially inseparable aspects of human existence. Religion and culture are twins and inter-dependent aspects of human life. Religion and culture are so intimately related and connected that in reality, it is impossible for society to have a culture without religion or religion without culture. Thus "no culture has appeared or developed except together with a religion. ${ }^{, 24}$ Religion and culture are two inseparable facets of one human reality. ${ }^{25}$

\section{INCULTURATION, INTEGRATION AND INDIGENISATION OF CHRISTIANITY}

The European missionaries who came to Asante Kingdom (Asanteman) in the 15th century onwards taught the Asantes that they must abandon their religion in order to become Christians. Despite this, it is an undeniable fact that some Asantes cling tenaciously to their religion and culture and pragmatically return to some elements of their religion when they suit their cause. Thus, Busia queried, can the African be Christian only by giving up his culture, or is there a way by which Christianity can ennoble it?"26

Williamson observed that the majority of Christians have accepted the Church in its outward forms, while their inward spirit is still ruled by the attitudes and outlook of the old culture. ${ }^{27}$ Williamson advocated for the integration of the Christian faith into Akan cultural categories if the church would become indigenous and relevant to the people it has been called to serve. ${ }^{28}$

Similarly, Opuni-Frimpong observed that "African Traditional Religion and the Christian faith were presented by Western missionaries as two different faiths. Thus, missionaries saw their task as calling the Akan into a new life." 29 The dichotomy between the two religions made the integration of the two religions difficult, if not impossible. Thus, Opuni-Frimpong said, "The Akan people were called into the Christian faith, not through their cultural understanding, but the European world-view." ${ }^{30}$ Given these, inculturation is the answer to the integration of the two religions.

\section{RESULTS AND FINDINGS ON INDIGENISATION OF CHRISTIANITY AMONG ASANTES}

In this section, the responses from a survey and interviews conducted in Ejisu Juaben Municipality among Roman Catholics, Methodists and Pentecostals in 2017 were analysed in order to ascertain whether an Asante can be truly Asante and truly Christian or whether an Asante Christian should abandon Asante Traditional Religion to become a Christian.

A demographic analysis of the data shows that out of the 360 respondents, 63 (17.5\%) were 16-19 years old, $132(36.7 \%)$ were $20-30$ years old, $55(15.3 \%)$ were 31 - 40 years of age, $37(10.3 \%)$ were $41-50$ years of age, $30(8.3 \%)$ were 51-60 years of age, and $43(11.9 \%)$ were 61 years and above. Seventeen (17) respondents did not indicate their age. The research indicates that most of the Churches surveyed were youthful and vibrant within the ages of 20-60 years ( 254 or $70.6 \%$ ). They represent the working class of our society.

Out of the 365 respondents, 15 (4.1\%) were illiterates, 66 (18.1\%) were students in Basic/Junior High School or holders of Basic Examination Certificate of Education; 93 (25.5\%) were students in Senior High School or holders of West African Senior Secondary Certificate of Education certificate and 191 (52.3\%) were students in tertiary level of education or graduates. Twelve (12) respondents did not indicate their educational qualifications. The results show that most of the respondents were educated between Junior High School and tertiary level and thus understood the issues under consideration. A small percentage (4.1\%) of the target population indicated they were illiterates, while the majority of $95.9 \%$ indicated that they had formal education - between primary school and tertiary education.

Table 2: Distribution of Respondents' view on whether "traditional beliefs and practices will die a natural death because of Christianity?"

\begin{tabular}{|l|l|l|}
\hline Responses & Frequency (n) & Percentage (\%) \\
\hline No & 212 & 58.7 \\
\hline Yes & 141 & 41.3 \\
\hline Total & 361 & 100 \\
\hline
\end{tabular}

\footnotetext{
$\overline{23}$ Richard H. Niebuhr, Christ and Culture (San Francisco, CA: Harper Collins Publishers, 2001), 33

24 Giorgio Zunini, Man and his Religion-Aspects of Religious Psychology (London, 1969), 145 in S.S. Iwe, Christianity, Culture and Colonialism in Africa. (Port Harcourt: R. S. N. C. (nd), 58.

25 Iwe, Christianity, Culture and Colonialism in Africa, 59.

${ }^{26}$ K. A. Busia, "The African World-View" in Kwabena Opuni-Frimpong, Indigenous Knowledge \& the Christian Mission: Perspectives of Akan Leadership Formation on Christian Leadership. (Accra: SonLife Press, 2012), 50.

27 S. G. Williamson, Christianity and African Culture. (Accra: Christian Council of the Gold Coast, 1995), vi.

28 Opuni-Frimpong, Indigenous Knowledge \& the Christian Mission, 67.

29 Opuni-Frimpong, Indigenous Knowledge \& the Christian Mission, 69.

30 Opuni-Frimpong, Indigenous Knowledge \& the Christian Mission, 70.
} 


\begin{tabular}{|l|l|l|}
\hline Missing Number & 16 & \\
\hline Source: Field Survey 2017
\end{tabular}

Source: Field Survey 2017

Table 2 indicates that the majority of respondents, $212(58.7 \%)$ out of 361 answered that traditional beliefs would not die a natural death while 141 (41.3\%) said it would. Sixteen (16) respondents did not answer this question.

Some interviewees were of the view that traditional religious beliefs are still relevant and would persist in the era of Christianity. For example, some Asante Christians resort to the use of curses "in case of theft to prove their innocence" (Interview, 2017). Some Asante Christians consult Traditional priests at traditional shrines "for childbearing, the cure to diseases, and quick answers to their problems. ${ }^{31}$ "

Table 3: Distribution of Respondents view on whether "Some Asante Christians are afraid of curses more than God."

\begin{tabular}{|l|l|l|}
\hline Responses & Frequency (n) & Percentage (\%) \\
\hline I Disagree & 76 & 20.5 \\
\hline Neither Agree nor Disagree & 21 & 5.6 \\
\hline I agree & 275 & 74 \\
\hline Total & 372 & 100 \\
\hline Missing Number & 5 & \\
\hline
\end{tabular}

Source: Field Survey 2017

Table 3 shows that out of 372 Christians, 275 (74\%) responded that some Asante Christians are afraid of curses more than God while 76 (20.5\%) disagreed. Five (5) respondents did not answer this question. Moreover, some Christians said they pronounce curses on others to "dispense justice; to establish the truth; to exonerate themselves when falsely accused; out of mere hatred for the other; when they are offended; when they lose their property; and when a lie is told about them." 32

Table 4: Distribution of Respondents view on some elements that draw some Asante Christians to African Traditional Religion: "charms and amulets."

\begin{tabular}{|l|l|l|}
\hline Responses & Frequency (n) & Percentage (\%) \\
\hline I Disagree & 84 & 22.5 \\
\hline Neither Agree nor Disagree & 29 & 7.8 \\
\hline I Agree & 259 & 69.6 \\
\hline Total & 372 & 100 \\
\hline Missing Number & 5 & \\
\hline
\end{tabular}

Source: Field Survey 2017

Table 4 shows that out of 372 Christians, $259(69.6 \%)$ answered that charms and amulets are some elements that draw some Christians to African Traditional Religion while 84 (22.5\%) disagreed. Five (5) Christians did not answer this question. It was evident in the study that some Asante Christians continue to use charms and amulets. Some Asante Christians are afraid of witches and ghosts and believe in the potency of charms and amulets to aid them in times of calamity ${ }^{33}$ These Christians see nothing wrong in using some elements of traditional religion prohibited by the gospels. Rather, they believe they are fulfilling Jesus' teaching to "Render to Caesar the things that are Caesar's; and to God the things that are God's." 34

Table 5: Distribution of Respondents view on "Fear and Protection from Witchcraft"

\begin{tabular}{|l|l|l|}
\hline Responses & Frequency (n) & Percentage (\%) \\
\hline I Disagree & 94 & 25.4 \\
\hline Neither agree nor disagree & 26 & 7.0 \\
\hline I Agree & 250 & 67.6 \\
\hline
\end{tabular}

\footnotetext{
Interview, 2017.

32 Interview, 2017.

33 Williamson, Akan Religion and the Christian Faith, 81.

Matthew 22:21.
} 


\begin{tabular}{|l|l|l|}
\hline Total & 370 & 100 \\
\hline Missing Number & 7 & \\
\hline
\end{tabular}

Source: Field Survey 2017

Table 5 shows that out of 370 Christians, $250(67.6 \%)$ answered that some Christians seek protection from elements of African Traditional Religion because they are afraid of witchcraft while 94 (25.4\%) disagreed. Seven (7) Christians did not answer this question. The fear of witchcraft by some Christians including Asantes, and the recourse to Asante Traditional Religion for an antidote to it confirmed Benedict XVI's statement in his Post Synodal Apostolic Exhortation, Africae Munus:

Witchcraft, which is based on the traditional religions, is currently experiencing a certain revival. Old fears are re-surfacing and creating paralyzing bonds of subjection. Anxiety over health, well-being, children, the climate, and protection from evil spirits at times lead people to have recourse to practices of traditional African religions that are incompatible with Christian teaching. The problem of "dual affiliation" - to Christianity and the traditional African religions - remains a challenge. Through profound catechesis and inculturation, the Church in Africa needs to help people to discover the fullness of Gospel values. It is important to determine the profound meaning of these practices of witchcraft by identifying the many theological, social and pastoral implications of this scourge. ${ }^{35}$

Table 6: Distribution of Respondents' view on "Appreciation of the role of Asante Traditional Religion and culture as foundation or preparation to Christianity"

\begin{tabular}{|l|l|l|}
\hline Responses & Frequency (n) & Percentage (\%) \\
\hline I Disagree & 66 & 19.9 \\
\hline Neither Agree nor Disagree & 48 & 13.0 \\
\hline I Agree & 255 & 69.1 \\
\hline Total & 369 & 100 \\
\hline Missing Number & 8 & \\
\hline
\end{tabular}

Source: Field Survey 2017

The results in Table 6 show that out of 369 Christians, 255 (69.1\%) responded that Christianity must appreciate Asante Traditional Religion and culture as the foundation of or preparation for Christianity while 66 (17.9\%) disagreed. Eight (8) respondents did not answer this question. Most of the Christians surveyed responded that Traditional Religion and culture are the basis or foundation upon which Christianity is built. An interviewee answered:

I think we should let them appreciate their culture as Asantes. Things that are not against our Christian faith can

be adopted. But at the same time also as Christians, they must avoid certain things like cursing or going to the traditional shrine. ${ }^{36}$

Rahner agrees that the religions of pre-Christian humanity are legitimate, lawful and possess the grace of God just like the rest. ${ }^{37}$ Thus, missionaries do not bring God to people who are completely ignorant of God but turn an anonymous Christian into someone who knows God and is endowed with the grace of God already. The missionary brings Christ to someone who has incomplete knowledge of the Trinitarian God. ${ }^{38}$

Table 7: Distribution of Respondents' views on “Genuine Dialogue between Christianity and Asante Traditional Religion and Culture"

\begin{tabular}{|l|l|l|}
\hline Responses & Frequency (n) & Percentage (\%) \\
\hline I Disagree & 39 & 10.6 \\
\hline Neither Agree nor Disagree & 38 & 10.4 \\
\hline I Agree & 290 & 79.1 \\
\hline Total & 367 & 100 \\
\hline Missing Number & 10 & \\
\hline
\end{tabular}

Source: Field Survey 2017

\footnotetext{
35 Benedict XVI, Post Synodal Apostolic Exhortation, Africae Munus, (The Commitment of Africa). (Takoradi: Franciscan Press, 2011).

36 Anomah, "Assessing the Impact of Christianity on African Christians."; Interview, 2017

7 Rahner, "Christianity and the Non-Christian Religions," 121.

8 Anomah, "Assessing the Impact of Christianity on African Christians."
} 
As indicated in Table 7, out of 367 Christians, 290 (79.1\%) respondents agreed that a genuine dialogue between Christianity and Asante Traditional Religion and culture is necessary while 39 (10.6\%) disagreed. Ten (10) Christians did not answer this question. Some respondents observed that for a long time Christianity has not taken African Traditional Religion seriously. An interviewee said:

Dialogue between Christianity and Asante Traditional Religion to open a friendly and better atmosphere for unity in diversity; that is, an incarnation of the Good News in Asante culture. We need an African Council, like that of Medellin and Puebla in South America, to respond to the evangelical problems in Africa. Such a Council will be able to communicate faith to the Africans without imposing on them the Western culture as Belloc wrote, not many years ago, that 'Europe is the faith and the faith is Europe'. ${ }^{39}$

In support of the call for dialogue, Arinze encouraged Church leaders in Africa to promote the study of African Traditional Religion. He urged those responsible for theological training in seminaries and houses of formation for men and women religious to include the study of missiology and the great religions (especially African Traditional Religion and Islam in Africa) in their curriculum and select some priests and religious to specialise in African Traditional Religion and Islam so that they can lecture in these areas. ${ }^{40}$

Table 8: Distribution of Respondents' views on "Inculturation of the Gospel into Asante Culture"

\begin{tabular}{|l|l|l|}
\hline Responses & Frequency (n) & Percentage (\%) \\
\hline I Disagree & 29 & 8.0 \\
\hline Neither Agree nor Disagree & 37 & 10.1 \\
\hline I Agree & 299 & 81.9 \\
\hline Total & 365 & 100 \\
\hline Missing Number & 12 & \\
\hline
\end{tabular}

Source: Field Survey 2017

Table 8 shows that out of 365 Christians, 299 (81.9\%) agreed that inculturation of the Gospel into Asante Traditional Religion and culture is a key to a better understanding of the Christian message while 29 (8\%) disagreed. Twelve (12) Christians did not answer this question. The Asante Christian would be proud to see Christianity using his/her traditional religious elements and culture in worship and the liturgy. This would make him/her feel at home with Christianity. An interviewee answered:

A proper inculturation which does not scratch the surface but touches on the philosophy, the concepts and thought patterns of the people should be employed. The inculturation approach should touch the core of the Asante Christian. $^{41}$

Table 9: Distribution of Respondents' views on "Rites of Passage"

\begin{tabular}{|l|l|l|}
\hline Responses & Frequency (n) & Percentage (\%) \\
\hline I Disagree & 83 & 22.4 \\
\hline Neither Agree nor Disagree & 61 & 16.5 \\
\hline I Agree & 226 & 53.5 \\
\hline Total & 370 & 100 \\
\hline Missing Number & 7 & \\
\hline
\end{tabular}

Source: Field Survey 2017

Table 9 indicates that out of 370 Christians, 226 (53.5\%) responded that Christianity could adopt the Asante initiation rites of passage. However, 83 (22.4\%) disagreed. There were seven (7) Christians who did not answer this question. Some interviewees were of the view that Christianity could inculturate the Asante rites of passage into the Christian rites of passage, namely naming ceremony, puberty rites, marriage ceremony, funeral and burial rites.

\footnotetext{
39 Anomah, "Assessing the Impact of Christianity on African Christians."

40 Francis Arinze, "Pastoral Attention to Traditional Religions,"

https://www.vatican.va/roman_curia/pontifical_councils/interelg/documents/rc_pc_interelg_doc_21111993_trad-relig_en.html;

Anomah, "Assessing the Impact of Christianity on African Christians."

41 Anomah, "Assessing the Impact of Christianity on African Christians."; Interview, 2017.
} 
Table 10: Distribution of Respondents' views on "Singing, drumming and Dancing in Worship"

\begin{tabular}{|l|l|l|}
\hline Responses & Frequency (n) & Percentage (\%) \\
\hline I Disagree & 20 & 5.3 \\
\hline Neither Agree nor Disagree & 6 & 1.6 \\
\hline I Agree & 347 & 93.0 \\
\hline Total & 373 & 100 \\
\hline Missing Number & 4 & \\
\hline
\end{tabular}

Source: Field Survey 2017

In Table 10, out of 373 Christians, 347 (93\%) responded that Christianity could adopt the Asante's style of singing, drumming and dancing into Christian worship. Only 20 (5.3\%) Christians disagreed. There were four (4) Christians who did not answer this question.

Some Asante Christians were of the view that Christianity can adopt the warmth, the colourful, the rhythmic hand-clapping, singing and drumming available in African Traditional Religion. ${ }^{42}$

Table 11: Distribution of Respondents' views on "Martyrdom for one's belief"

\begin{tabular}{|l|l|l|}
\hline Responses & Frequency (n) & Percentage (\%) \\
\hline I Disagree & 56 & 15.4 \\
\hline Neither Agree nor Disagree & 74 & 20.4 \\
\hline I Agree & 233 & 64.2 \\
\hline Total & 363 & 100 \\
\hline Missing Number & 14 & \\
\hline
\end{tabular}

Source: Field Survey 2017

Table 11 shows that out of 363 Christians, 233 (64.2\%) responded that the Christian practice of suffering martyrdom for the sake of the gospel of Christ would confirm Asante Traditional Religion while 56 (15.4\%) disagreed. Fourteen (14) Christians did not answer this question. For example, a respondent explained that in the history of the Asante Kingdom, Nana Tweneboa Kodua, the Omanhene of Kumawu Traditional Area laid down his life for the Asante people when the chief priest of Asante, Okomfo Anokye requested for human sacrifice to be made for the unity and stability of the Asante Kingdom. Similarly, Nana Dikopim gave up his life for similar reasons. These acts of self-giving for the sake of their beliefs are in line with Christ's self-emptying and redemptive work on the cross. ${ }^{43}$

The Second Vatican Council affirms Christ's suffering and death on the cross out of love for the sins of all people so that all might attain salvation. ${ }^{44}$

Table 12: Distribution of Respondents on some elements in Asante Culture that Christianity can emulate?" "Initiation Rites."

\begin{tabular}{|l|l|l|}
\hline Responses & Frequency (n) & Percentage (\%) \\
\hline I Disagree & 83 & 22.4 \\
\hline Neither agree nor disagree & 61 & 16.5 \\
\hline I Agree & 226 & 53.5 \\
\hline Total & 370 & 100 \\
\hline Missing Number & 7 & \\
\hline
\end{tabular}

Source: Field Survey 2017

Table 13 shows that out of 370 respondents, 226 (53.5\%) accepted that Christianity could adopt the Asante initiation rites. However, 83 (22.4\%) disagreed. There were seven (7) respondents who did not answer this question. They agreed that the elaborate way of initiating Asantes into their culture can be emulated by Christians. Some interviewees agreed that Christianity could integrate the Asante rites of passage into the Christian rites of passage.

\footnotetext{
42 Williamson, Akan Religion and the Christian Faith, 164.

43 Alexander Jones (General Ed.), John 10:11-18, Philippian 2:6-11, New Jerusalem Bible, Popular edition (London: Darton, Longman, 1974).

44 Vatican II, Declaration on the Relations of the Church to Non-Christian Religions (Austin Flannery, Gen. Ed. Dublin: Dominican Publications, 1988 ), 2.
} 


\section{FINDINGS AND DISCUSSIONS}

The European Christian missionaries taught the Asante Christian to abandon his/her religion and adopt Christianity with all its external paraphernalia. As a result, many Asante Christians are neither Asantes nor Christians and live their lives in two worlds; and religions; Asante Traditional Religion and Christianity; depending on which one is convenient and helpful at any point in time and solves their existential needs. However, the Second Vatican Council teaches that the Church "does not wish to impose a rigid uniformity in matters which did not involve the faith or the good of the whole community." ${ }^{45}$ Rather, the Church "respects and fosters the qualities and talents of various races and nations" in so far as they do not involve superstition or error. ${ }^{46}$ Therefore, to make Christianity relevant to the Asantes, the Church must study the Asante culture and admit to the liturgy some Asante cultural practices as long as they harmonise with the spirit of the liturgy. Ecclesiastical authorities have the mandate of the Church to adapt the administration of the sacraments, sacramentals, liturgical language, sacred music and the arts in the liturgy. ${ }^{47}$ They have the power to prudently consider which elements from the traditions and culture are to be admitted into divine worship. ${ }^{48}$ Thus, traditional naming ceremony, puberty rites, marriage, funeral and burial rites could be integrated into the Christian baptism, confirmation, marriage and burial rites respectively, to save the time and money spent on multiple ceremonies.

Some Asante Christians have no qualms going to Church on Sunday morning and visiting a traditional priest of a traditional shrine in the afternoon if that will supply their existential needs. An interviewee admitted,

Somebody becomes a convinced Christian. She wants a child and cannot get it so she runs into trouble. She goes back to the former practices and seeks help from the traditional magical world. This is what is happening. There are many Catholics and many Christians who will never under any circumstance abandon their faith. There are many Christian who are Christian when they get what they want, but have no qualms going back to the former magico-traditions Christianity. ${ }^{49}$

The study realised that some Asante Christians are afraid of witches and evil spirits and use charms and amulets to protect themselves. Some Asante Christians consult traditional priests of traditional shrines, and medicine-men because of fear of witchcraft. They seek protection from charms and amulets against witchcraft powers. Some Asante Christians are afraid of witches and seek protection from the gods by consulting traditional priests of traditional shrines and medicine men. A respondent believes that traditional priests provide some mystical objects for the protection of families, property, homes and individuals, e.g. charms, amulets and bracelets. They use their knowledge and manipulation of this mystical power for the welfare of their community. They administer herbs for healing physically. They also heal supernaturally. ${ }^{50}$ Similarly, some Asante Christians curse others out of revenge; to exonerate themselves from false accusations or when their property is stolen. Some respondents believe that some Asante Christians pronounce curses on others in anger; to avoid shame; to protect their good name when accused of something they have not done; when people steal their properties; when it becomes known that their wives or husbands are not faithful to them. ${ }^{51}$

It is noteworthy to say that even in the twenty-first century when the judicial services are well advanced in Ghana, some Asante Christians still resort to the use of curses instead of the judicial system because they believe some judges are corrupt and unjust. ${ }^{52}$

It also came to light that Christianity could integrate the Asante traditional rite of passage into the Christian rite of passage to avoid the multiplication of rites by Asante Christians. Although the study was undertaken among the Asantes in Ejisu Juaben Municipality in the Ashanti Region of Ghana, the issue of dual religiosity could be applied to other contexts in Ghana, Africa and elsewhere in the world.

\section{RECOMMENDATIONS}

The study recommends that Asante Christians should recognise Asante Traditional Religion as a lawful and legitimate religion endowed with divine grace and appreciate it as the foundation of Christianity among the Asantes.Asante Christians should dialogue with Asante Traditional Religion, adopt elements, practices, and beliefs that are not superstitious and against the gospel and inculturate or integrate them into Christianity.

The study also recommends that Christianity should integrate Asante traditional religious rites of passage (i.e. naming ceremony, puberty rites, marriage rites, burial and funeral rites) into the Christian rites of passage, and use singing, dancing and drumming in the Christian worship so that the Asante Christian would be firmly integrated into

\footnotetext{
45 Vatican II, The Constitution on the Sacred Liturgy, (Iperu-Remo: Ambassador Publications, 1998), SC 37, 13; Anomah, “Assessing the Impact of Christianity on African Christians."

46 Vatican II, The Constitution on the Sacred Liturgy, SC 40, 14; Anomah, "Assessing the Impact of Christianity on African Christians."

47 Vatican II, The Constitution on the Sacred Liturgy, SC 39, 14; Anomah, "Assessing the Impact of Christianity on African Christians."

48 Vatican II, The Constitution on the Sacred Liturgy, SC 40, 14; Anomah, "Assessing the Impact of Christianity on African Christians."

49 Anomah, "Assessing the Impact of Christianity on African Christians."; In-depth interview, 2017.

50 Anomah, "Assessing the Impact of Christianity on African Christians."; Interview, 2017

51 Anomah, "Assessing the Impact of Christianity on African Christians."

52 Anomah, "Assessing the Impact of Christianity on African Christians."
} 
Asante Traditional Religious culture and Christianity and be truly Asante and truly Christian.

\section{CONCLUSION}

In conclusion, Asante Christians do not necessarily have to abandon Asante Traditional Religion and culture to become Christians. Rather, they become truly Asante and truly Christian by integrating or inculturating elements, practices and beliefs in Asante Traditional Religion (in so far as they are not contrary to the Gospel) into the Gospel. The Church teaches and respects the religion and culture of people of every nation; and encourages Christians to study and adapt the language, religion, music, arts, drumming, dancing, gestures, worship, and dressing of the people with whom they live; adopt and harmonise them into the liturgy so long as they are not superstitious and contrary to the Gospel of Christ. Moreover, Asante Christians should have great faith in God's power to protect and save them from adversity, evil powers, or forces rather than fear curses and witchcraft; and use charms and amulets for the protection of themselves and their properties. The lack of strong faith in God's power over evil spirits influences some Asante Christians to resort to the use of charms and amulets in secret for protection and favour.

Thus, by integrating the good and time-tested values, beliefs and practices of Asante Traditional Religion into the Gospel, the Asante will be firmly integrated into both Christianity and Asante Traditional Religious beliefs and practices and therefore be truly Asante and truly Christian without resorting to prohibited practices in secret.

\section{ABOUT THE AUTHOR}

Rev. Fr. Anthony Kofi Anomah ( $\mathrm{PhD})$ is a Catholic religious missionary priest of the Congregation of the Holy Spirit, Province of Ghana. He is currently the Rector of the Spiritan University College, Ejisu, Ghana; and a member of the Ghana Psychology Council. His research interests are in the Church, Christianity and culture. He has published several articles in both local and foreign journals on issues in his research interest.

\section{BIBLIOGRAPHY}

Addai-Mensah, Peter \& Opoku, John. K. "Christ and the Religions: A Critique of the Pluralistic and the Exclusivist Paradigms," Journal of Applied Thought (A Multidisciplinary Approach), 3, no. 1 (2014).

Anomah, Anthony Kofi, "Assessing the Impact of Christianity on African Christians: A Case study of some selected Churches in Ejisu Juaben Municipality.” PhD Thesis unpublished, Kwame Nkrumah University of Science and Technology, Kumasi, 2019.

Arinze, Francis. "Pastoral Attention to Traditional Religions" Pastoral Council for Interreligious Dialogue (1993). Accessed July 26, 2016.https://www.vatican.va/roman_curia/pontifical_councils/interelg/documents/rc_pc interelg_doc_21111993 trad-relig_en.html

Busia, K. A. The Position of the Chief in Modern Political System of Ashanti. Oxford: Oxford University Press, 1958.

Flannery, Austin (Gen. Ed.). Vatican II, Declaration on the Relations of the Church to Non-Christian Religions. Dublin: Dominican Publications, 1988.

Gbortsu, Fabian, "Facing Spiritual Insecurity: Christian Faith and the Return of Catholics to the African Traditional Religion in Challenges to Church's Mission in Africa (edited by Fabrizio Meroni).(Rome: The Factory S.r.l., 2020).

Iwe, S. S. Christianity, Culture and Colonialism in Africa. Port Harcourt: R. S. N. C. (nd).

Jones, Alexander (General Ed.), John 10:11-18, New Jerusalem Bible, Popular edition London: Darton, Longman, 1974.

Koren, J. Henry. Spiritan West Africa Memorial for Gambia, Sierra Leone, Liberia and Ghana - 1842-1996. Bethel Park, PA: Spiritus Press, 1997.

Krejcie, R.V and Morgan, D. W. Determining Sample Size for Research Activities. Educational and Psychological Measurement. (1970), 30, 607-610.

Mbiti, John S. African Religions and Philosophy. London: Heinemann, 1998.

Niebuhr, Richard H. Christ and Culture. San Francisco, CA: Harper Collins Publishers, 2001.

Obeng, Pashington. Asante Catholicism: Religious and Cultural Reproduction Among the Akan of Ghana. New York, NY: E. J. Brill, 1996.

Opuni-Frimpong, Kwabena. Indigenous Knowledge \& Christian Missions: Perspectives of Akan Leadership Formation on Christian Leadership Development. Accra: SonLife Press, 2012.

Rahner, Karl. "On the Importance of the Non-Christian Religions for Salvation," Theological Investigations, 18. London: Darton, Longman \& Todd, 1984. 
. "Christianity and the Non-Christian Religions," Theological Investigations, 5. London: Darton, Longman \& Todd, 1966.

Vatican II, The Constitution on the Sacred Liturgy. Iperu-Remo: Ambassador Publications, 1998.

Williamson, S. G. Akan Religion and the Christian Faith: A Comparative Study of the Impact of the Two Religions. Accra: Ghana University Press, 1974. 